\title{
Aviation Fueling: A Cleaner, Greener Approach
}

\author{
Robert C. Hendricks, ${ }^{1}$ Dennis M. Bushnell, ${ }^{2}$ and Dale T. Shouse ${ }^{3}$ \\ ${ }^{1}$ NASA Glenn Research Center, 21000 Brookpark Road, Cleveland, OH 44135, USA \\ ${ }^{2}$ NASA Langley Research Center, Hampton, VA 23681, USA \\ ${ }^{3}$ AFRL/WPAFB, Wright-Patterson Air Force Base, OH 45433, USA \\ Correspondence should be addressed to Robert C. Hendricks, robert.c.hendricks@grc.nasa.gov
}

Received 24 December 2010; Revised 7 July 2011; Accepted 1 August 2011

Academic Editor: Ting Wang

Copyright ( $\odot 2011$ Robert C. Hendricks et al. This is an open access article distributed under the Creative Commons Attribution License, which permits unrestricted use, distribution, and reproduction in any medium, provided the original work is properly cited.

\begin{abstract}
Projected growth of aviation depends on fueling where specific needs must be met. Safety is paramount, and along with political, social, environmental, and legacy transport systems requirements, alternate aviation fueling becomes an opportunity of enormous proportions. Biofuels—sourced from halophytes, algae, cyanobacteria, and “weeds" using wastelands, waste water, and seawaterhave the capacity to be drop-in fuel replacements for petroleum fuels. Biojet fuels from such sources solve the aviation $\mathrm{CO}_{2}$ emissions issue and do not compete with food or freshwater needs. They are not detrimental to the social or environmental fabric and use the existing fuels infrastructure. Cost and sustainable supply remain the major impediments to alternate fuels. Halophytes are the near-term solution to biomass/biofuels capacity at reasonable costs; they simply involve more farming, at usual farming costs. Biofuels represent a win-win approach, proffering as they do—at least the ones we are studying—massive capacity, climate neutral-to-some sequestration, and ultimately, reasonable costs.
\end{abstract}

\section{Introduction}

We are dealing with opportunities of enormous proportions driven by conflicts between energy, food and freshwater demands, population growth, and climatic changes.

By 2026, world liquid fuels $[1,2]$ demand is projected to grow by $20-25 \%$, implying an increased US demand from over 20 million bbl/day (2007) to 24 million bbl/day. Even if algae could be grown on the open seas fed by continent-sized nutrient streams under the most opportune of conditions and converted to oils, in order to meet that demand with alternative fuels, the equivalent volume demand would require nearly half the Gulf of Mexico, 0.8 million $\mathrm{km}^{2}$ (Assumes equivalency between refined barrels of plant oil and petroleum. The Ami Ben-Amotz algae production is $\left(0.8 \times 10^{12} \mathrm{~m}^{2}\right)\left(0.02 \mathrm{kgbiomass} / \mathrm{m}^{2}\right.$-day $)(3 / 10 \mathrm{gal} / \mathrm{kg})$ (1/42 bbl/gal) (20\% bio-oil/biomass), and the John Benneman algae estimate is $\left(0.8 \times 10^{12} \mathrm{~m}^{2}\right)\left(4.2 \times 10^{3}\right.$ gal bio-oil/hayr) $\left(10^{-4} \mathrm{ha} / \mathrm{m}^{2}(1 / 365 \mathrm{yr} /\right.$ day $) 1 / 42 \mathrm{bbl} /$ gal $\left.).\right)$.

By 2026 the world's jet fuel consumption is also projected to grow from 95 billion gal (2007) to around 221 billion gal (3.785 L/gal or 836 billion liters) per year [3]. Replacing
$10 \%$ with a renewable jet fuel would be similar in scale to current worldwide liquid biofuels (ethanol and biodiesel) production. The need for replacement fueling and the effects of biofuels on both legacy and future aircraft performance and design have been established in prior publications [46]. These publications clearly illustrate the conflicts between fuel types and the crops and crop land necessary for alternate aircraft fueling. The aviation industry requires specific mobility fuels and cannot replace jet fuel with current renewable fuels (ethanol, biodiesel, or hydrogen electricity). It is, therefore, pursuing new, large-scale, secure, sustainable biofuels within several "do no harm" restraints including (i) not competing with arable land or freshwater resources needed for food/feed production, (ii) low carbon footprints that do not lead to deforestation, and (iii) not engendering adverse environmental or social impacts.

Two tons of jet fuel generate over 1.6 tons of carbon and over 2.5 tons of water when burned. Globally, aviation fuel has been growing at about $4 \%$ per year despite a $1 \%$ per year improvement in airplane fuel efficiencies. The resulting high-altitude cloud formations and carbon footprint $\left(\mathrm{CO}_{2}\right.$ emissions) are of increasing concern to the commercial 
aviation industry, which has set a goal that future growth in the industry should be carbon neutral. To meet this goal, renewable jet fuels are critical. The Commercial Aviation Alternative Fuels Initiative (CAAFI) and commercial aviation industry set a goal of certifying a blended renewable jet fuel in the 2009-2010 time frame. To reach this ambitious goal, a program is underway to establish the technical feasibility, environmental sustainability, and eventual commercial viability of renewable biojet fuels. Synthetic aviation fuels would require studies on the basic technical feasibility of synthetic paraffinic kerosene (SPK) jet fuels produced from coal or natural gas or of hydrogen-treated renewable jet fuels (HRJ) produced from vegetable oils or similar sources having the same properties as conventional jet fuels. This has already been proven through several flight demonstrations by the US Air Force, commercial airline partners, and four aircraft engine OEMs (original equipment manufacturers). The next stage is to develop secure scalable, sustainable, and economically viable feedstocks for biojet fuels that satisfy the aircraft industry's "do no harm" constraints and reduce their reliance on petroleum-based fuels.

This paper compiles a large amount of information regarding various biofuels possibilities. Conclusions were drawn from this data, considering the challenges that must be overcome and goals that need to be met to implement a successful biofueling system in the commercial aviation industry. Because the field is rapidly moving forward, new information such as on-wing testing and crop maintenance continues to emerge and requires new analysis. Some of these new considerations are discussed in the paper.

Potential sources for viable alternative biojet fuels include halophytes (micro- and macro-), algae, bacteria, weedsto-crops, wastes, and crop residue. Each of these has its benefits and also poses challenges for incorporation into aviation fueling (Table 1). In the following sections, we will further explore why biomass fueling is desirable; the available resources, feedstocks, and processing to satisfy aviation fueling specifications for flight applications; along with some economic and logistic problems. Future applications discussed include general aviation and unmanned aerial vehicles.

\section{Why Biomass Fueling}

We are a society addicted to hydrocarbons. Our planet is gripped by our addiction to hydrocarbon energy generation sources.

Addiction is a terrible thing. It consumes and controls us, makes us deny important truths and blinds us to the consequences of our actions. (U.N. Secretary-General Ban Ki-Moon)

We take pride in our clean, green identity as a nation and we are determined to take action to protect it. We appreciate that protecting the climate means behavior change by each and every one of us. (Prime Minister Helen Clark, New Zealand)
Both are valid convictions, yet will biomass fueling Reduce hydrocarbon addiction?

Reduce $\mathrm{CO}_{2}, \mathrm{NO}_{X}$, and so forth, nanoparticulate, altitude $\mathrm{H}_{2} \mathrm{O}$ clouds, and emissions health and climate hazards?

Reduce foreign control of our future?

Require cooperative worldwide investments?

Require a paradigm shift in source and use of energy?

The consequences of inaction are existential to humanity. Economic growth, testing, and projections of biomass production must address several questions in the face of worldwide issues. The population is expected to grow approximately $40 \%$ in $40-50$ years, aviation is projected to grow at $4 \%$ per year, and 220 billion gallons of jet fuel is projected to be used in 2026 (95 billion gallons used in 2007 alone). Fuel burn reductions are projected to be $15 \%$ by air traffic management (ATM), $50 \%$ by future aircraft designs, and $25 \%$ by future engine designs (intercool, recuperator, and respecting the laws of thermodynamics). Legacy aircraft with, future ATM and future fleet, implies fleet (2026) will have less than $40 \%$ fuel burn reduction. Given these issues, $\mathrm{CO}_{2}$ goals of greater than $80 \%$ reduction without increase of other emissions and aviation ground rules limiting fueling options to "do no harm" cannot be met. These issues and goals are recognized by aviation and fueling industries, but not by the space industry, which poses the question of whether aerospace will grow, decline, or equilibrate. Alternative fueling requires a paradigm shift in our conception of, source of, use of, and funding of energy. A reduced dependence on coal, gas, and nuclear energies will cost more. By giving serious consideration to all the issues addressed, biomass fueling could provide a resolution to the future of aerospace using multiple resources. Currently, our resources are $97 \%$ seawater, $43 \%$ arid land, and a solar source of energy, and our goals are to conserve freshwater and arable land and to protect our food supply, health, and climate.

The real problems we face are how to make these fuel resources

secure,

sustainable,

economically viable,

sufficiently available,

all while satisfying the ground rules.

The questions, issues, and problems addressed lead to the conclusion that we must use Earth's most abundant natural resources, which are biomass, solar energy, arid land $(43 \%)$, seawater $(97 \%)$ with nutrients $(80 \%)$, plus brackish waters and nutrients to resolve the environmental triangle of conflicts between energy, food, and freshwater; also, we must mitigate ultrafine particulate hazards. This accomplishment requires a paradigm shift: we must develop and use solar for energy (in the form of virtually any renewable fossil fuel replacement resource: photovoltaic, thermal, wind, and drilled geothermal); biomass for aviation; 
and hybrid-electric-compressed air mobility fueling with transition to hydrogen in the long term. Also, we must employ telecommunication (tele-everything).

\section{Biomass Resources}

Today's world food supply depends on four major crops: rice, corn (maize), wheat, and soybeans, which provide $80 \%$ of consumed calories. Gressel [15] points out that we are "just one crop short of disaster," with food production also consuming and dependent upon large amounts of freshwater (see Table 2 and Figure 1) [15, 16]. Ho and Cummins [17] cite major issues involving freshwater shortages that threaten world food supply as being more serious than the shortage of fossil fuels, yet "cultivating salt-tolerant crops could solve both problems."

These realities engender the food or fuel issues and their detriments, benefits, and limitations. Gressel [7] argues for biomass diversity and that biomass production (e.g., switchgrass) does not defy uptake of essential nutrients such as water and nitrogen (Figure 1); freshwater demands are given in Table 2.

Gressel [7] proposes that the food-feed-fuel issue cannot be resolved within the framework of genetics alone, pointing out several problems such as (1) does one develop and use algae or cyanobacteria, (2) how to contain unwanted organisms, (3) transgenetic spillage and "going wild" again, and (4) oil content and coproduct proteins (feed). Ho and Cummins [17] discuss some aspects of transgenetic crops while favoring domestication of wild halophytes, identifying genes involved in plant salt tolerance and crop improvements through marker-assisted breeding. Gressel [15] also points out that often coproduct values are higher than the oil content, as is often the case for corn and soybean meals.

While freshwater is a renewable resource, and peakwater estimates are inaccurate, peak ecological water results from climatic anthropogenic changes [16]. Many watersheds are running low, as is occurring in the Canadian Rocky Mountains, because of glacier melt and lack of snow mass and intensive Colorado River (southwestern United States) water demands, of which much is used for crop irrigation. As a result of high demand and low water levels, many aquifers are slowly becoming saline.

Conservation of arable land and freshwater biodiverse regions along with the development of saline agriculture and aquiculture can provide proteins, oils, as well as renewable biomass resources for food, medicines, livestock feed, and fuel. Arguments and justification for use of world sea and brackish water along with arid and semiarid land and agriculture and human wastes as sustainable fuel and food resources have been presented previously $[18,19]$.

Adherence to conservation and selective cultivation practices establish "do no harm" ground rules for aviation fueling as our first set of limitations [20,21]:

(1) does not compete with arable land food or feed production,

(2) does not require freshwater resources,

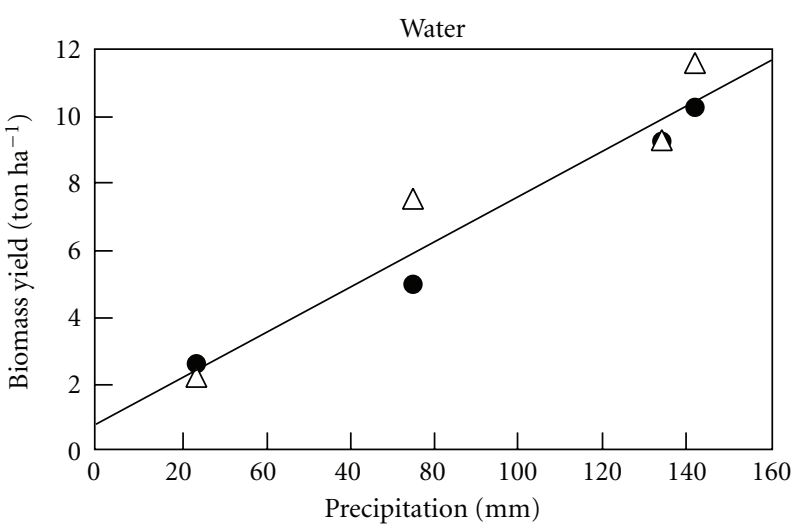

(a)

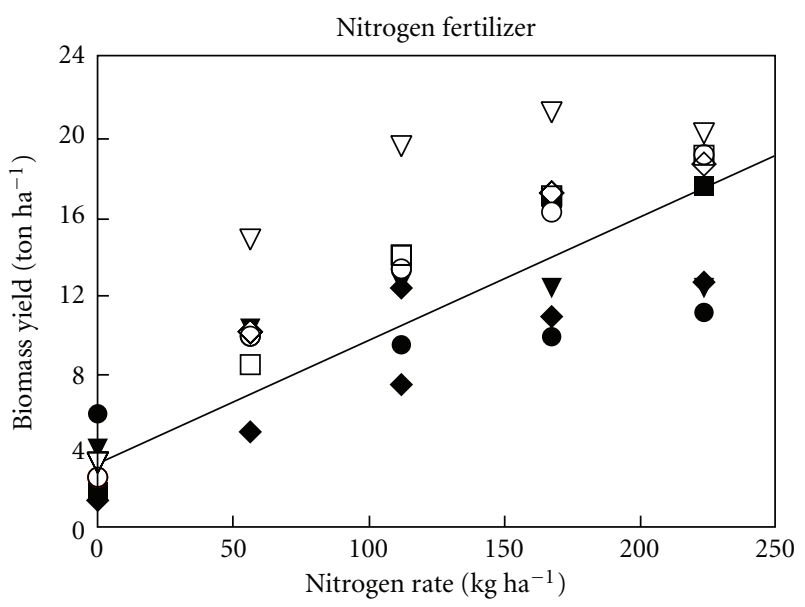

(b)

FigURE 1: Biomass productivity depends on water and nutrients [7].

(3) does not cause deforestation or adverse social or environmental harm,

(4) can be scaled to assure secure sustainable sufficient supply,

(5) can be competitive with JP-8 or JetA-1,

(6) life cycle carbon reduction, $>50 \%$ fossil $\mathrm{CO}_{2}$ reduction.

\section{Biomass Feedstock Potential Resources}

Biomass feedstock sources include halophytes (micro- and macro-), algae, bacteria, weeds-to-crops, and wastes. Algae are prolific producers and are promoted by many scientists as the solution to our energy dilemma. Reviews by the Sustainable Energy Ireland found that algae could prosper in the lower temperature and sunlight and produce fuels at costs higher than today's petroleum market prices [22]. Professor Ami Ben-Amotz and Dr. John Benemann serve as resource persons for any individual or corporation further interested in algae production, as dealing with living cultures and sustainability is quite involved. The major issue with algae fueling is cost, and much attention is currently given to this issue $[3,5,23-25]$. 
TABLE 1: Overview of biomass resources.

\begin{tabular}{|c|c|c|c|c|}
\hline Resource & Pros & Cons & Types & Key points \\
\hline \multirow{4}{*}{$\begin{array}{l}\text { Halophytes } \\
\text { (micro and macro) }\end{array}$} & $\begin{array}{l}\text { (i) Salt water and } \\
\text { brackish water tolerant }\end{array}$ & (i) Requires more farming & \multirow[t]{4}{*}{ Seashore mallow } & (i) Seawater irrigation \\
\hline & $\begin{array}{l}\text { (ii) Byproducts are very } \\
\text { useful for other } \\
\text { purposes }\end{array}$ & $\begin{array}{l}\text { (ii) Undeveloped } \\
\text { agriculture and aquaculture }\end{array}$ & & $\begin{array}{l}\text { (ii) Harvested using conventional } \\
\text { equipment }\end{array}$ \\
\hline & (iii) Cost effective & & & $\begin{array}{l}\text { (i) Growth in various saltwater } \\
\text { environments }\end{array}$ \\
\hline & $\begin{array}{l}\text { (iv) Good near term } \\
\text { solution }\end{array}$ & & & \\
\hline \multirow{11}{*}{ Weed-to-Crop } & $\begin{array}{l}\text { (i) Includes crops such } \\
\text { as soybeans, canola, } \\
\text { rapeseed }\end{array}$ & $\begin{array}{l}\text { (i) Weeds require } \\
\text { developed agriculture }\end{array}$ & Camelina & $\begin{array}{l}\text { (i) Matures in } 85-105 \text { days, yield } 3.2 \\
\text { tonne/ha } 35 \%-45 \% \text { oil }\end{array}$ \\
\hline & & & & $\begin{array}{l}\text { (ii) Crop residue potential as pyrolysis } \\
\text { fuel }\end{array}$ \\
\hline & & & \multirow{4}{*}{ Pennycress } & (iii) Grows in nutrient poor soil \\
\hline & & & & $\begin{array}{l}\text { (i) } 0.25 \text { tonne/ha oil seed with } 36 \% \\
\text { oil/seed }\end{array}$ \\
\hline & & & & $\begin{array}{l}\text { (ii) potential to produce } 920 \\
\text { L-biodiesel/ha }\end{array}$ \\
\hline & & & & $\begin{array}{l}\text { (iii) competes with arable land and } \\
\text { fresh water resources }\end{array}$ \\
\hline & & & \multirow{5}{*}{ Castor } & (i) Nonedible \\
\hline & & & & (ii) Low water demand \\
\hline & & & & $\begin{array}{l}\text { (iii) } 40 \%-60 \% \text { seed oil content by } \\
\text { mass }\end{array}$ \\
\hline & & & & (iv) $90 \%$ reduction in GHG \\
\hline & & & & (v) Seed contains ricin \\
\hline
\end{tabular}

(i) Good candidates for fermentation fuels

(ii) 1 ton of biomass produces $100 \mathrm{gal}$ of ethanol pyrolysis or (i) Negative environmental

impact if harvested (erosion and overall decrease in soil health possible)

(ii) Large-scale production is challenging
Lignocellulosic (includes crop residues) (v) Seed contains ricin

(i) Noxious weed

(ii) Remediates waste water

(iii) Source of pyrolysis fuels

(iv) $5-10 \mathrm{~kg}$-biomass $/ \mathrm{m}^{2}$-yr

(i) Noxious weed

Kudzu (ii) Pyrolysis benefits similar to water hyacinth

(i) Produce oil seeds for processing

Honge into biodiesel

(ii) Tolerate brackish water

(iii) Little nitrogen fertilizer needed (i) Prolific producers

(ii) Enhanced percentage oil/biomass

Algae (i) Marine: difficult to modify

(ii) Wavelength and time of exposure of light affect productivity
(iii) Enhanced solar spectra absorption
(iv) Environmental adaptivity growth needed to meet full (iii) Costly

(iv) Large volume of demand (i) Tolerates salt-water

Varieties 
TABLE 2: Freshwater demand for selected staple and associated crops, goods, and beverages [16].

\begin{tabular}{|c|c|c|c|}
\hline \multicolumn{2}{|c|}{ Liter (water)/liter (product) } & \multicolumn{2}{|c|}{ Liter (water)/kg (product) } \\
\hline Bottled water & $3-4$ & Cup of coffee & 1120 \\
\hline Milk (process/cow) & $7 / 1000$ & Bread & 1300 \\
\hline Glass of beer & 300 & Cotton & 11000 \\
\hline Glass of orange juice & 850 & Hamburger & 16000 \\
\hline \multirow[t]{10}{*}{ Glass of wine } & 950 & Microchip & 16000 \\
\hline & & Roasted coffee & 21000 \\
\hline & & Coconut & 2500 \\
\hline & & Sugar & 1500 \\
\hline & & Barley & 1300 \\
\hline & & Alfalfa & $900-2000$ \\
\hline & & Wheat & $900-2000$ \\
\hline & & Corn/Maize & $1000-1800$ \\
\hline & & Soybeans & $1100-2000$ \\
\hline & & Rice & $1900-5700$ \\
\hline
\end{tabular}

In an attempt to address economics and biomass production, Hendricks and Bushnell looked to the nutrientrich Gulf of Mexico and floating biomass growth scaffolds [24]. Even under the most favorable conditions-for only US domestic commercial use-a 50:50 biojet : JetA-1 blend ( 26.5 billion $\mathrm{L} / \mathrm{yr}$ or 7 billion gal/yr) requires a $22,500 \mathrm{~km}^{2}$ growth area, nearly the size of the Gulf's $21,000 \mathrm{~km}^{2}$ hypoxic zones (lack of oxygen, "dead zones") [26]. This is a large area to manage in view of the risks, including storms and invasive species [27]. Here, biomass cultivation may be feasible as dead zone remediation $[26,28]$ and as a fuel feedstock source. The objective of the Mississippi River Delta project [24, Appendix]-where the focus is on prevention and remediation-is to neutralize sources engendering hypoxic zones. Perhaps both are feasible. It should also be noted that $63 \%$ of petroleum leakage into North American waters comes from natural seepage and 33\% from user spills [13].

Venter's fourth-generation synthetic fuels [33] with promises for enhanced productivity due to enhanced percentage oil/biomass, solar spectra absorption, and environmental adaptivity have been given a major investment boost. Modifying marine algae, however, is not that simple; it has not been very successful in the past and may be more difficult to manipulate than higher plants [34]. Further, the effects of light - both the wavelength and time of exposurehave a demonstrated direct effect on plant communication, reproduction, and biomass growth that requires assessment [35].

Halophytes are salt-water-tolerance and brackish-watertolerant plants that address the environmental triangle of conflict issues (food, energy, water). Seawater is $35,000 \mathrm{ppm}$ salt. One cannot drink water with more than 3,000 ppm, and normal potable water is $500 \mathrm{ppm}$. Salicornia, seashore mallow (grain and straw crops), and Distichlis spicata (a remedial grass) are a sampling of thousands of halophyte species [18]. Halophytes are also convenient in terms of production capabilities; because of their adaptability, they can be grown near any coastal region. This creates both a distributed feedstock source and fueling system, eliminating the need to process and ship fuel great distances to meet demand.

The potential of salicornia (among other halophyte species) has been heavily investigated by Dr. Hodges (Seawater Foundation) and Glenn (University of Arizona) as well as at NASA Glenn Research Center's Green Lab. The adaptability of growth and lipid production was analyzed, and the salicornia species ability to grow in various seawater environments is remarkable and relevant. Different salicornia species were observed to produce lipid contents based on different variables.

In seeking suitable seed and cellulosic biomass, plant genesis becomes a good indicator of utility. Seashore mallow belongs to the Malvaceae family, which includes kenaf, okra, and cotton (Figure $2[8-10]$ ). Additional potential markets include fibers, bioplastics, food/feed, and pyrolysis fuels.

Seashore mallow is harvested using conventional equipment. Halophytes can sequester salts at the roots or in the foliage. At the roots, excess saltwater/brackish water is used to flush the soils to provide nutrients and prevent significant salt buildup. For foliage, some grasses are considered forage grasses where the ruminant livestock seem to thrive. In other cases, the calcium or sodium chloride $\left(\mathrm{CaCl}_{2}\right.$ or $\left.\mathrm{NaCl}\right)$ is secreted as surface nodules and plant (tree) biomass as carbon sequestration in carbon trading schemes. The collection and disposal of salts en masse has not yet been addressed other than via dilution. Other uses include high-quality sea salt as common-salt replacement. Seawater irrigation requirements are higher than freshwater irrigation, requiring adequate well-planned and -executed irrigation and drainage to control salt buildup in the root areas. However, for seashore areas as for the seashore mallows, the plant foliage and soil is also flushed with rainwater, so some balance must be achieved (see Table 3 ). In the life cycle system of Dr. Hodges [36], freshwater lenses are also developed to conserve freshwater.

Camelina is a weed-to-crop that can be intercropped [37]. It looks like wild mustard, can prosper on marginal lands, matures in 85-105 days, has small oil seeds that yield 


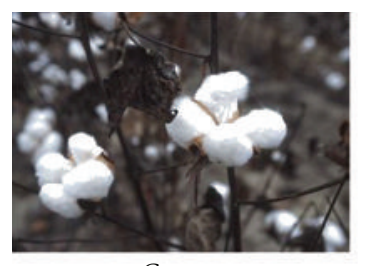

Cotton

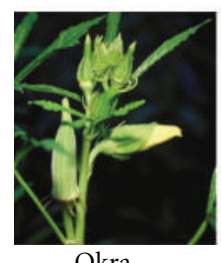

Okra

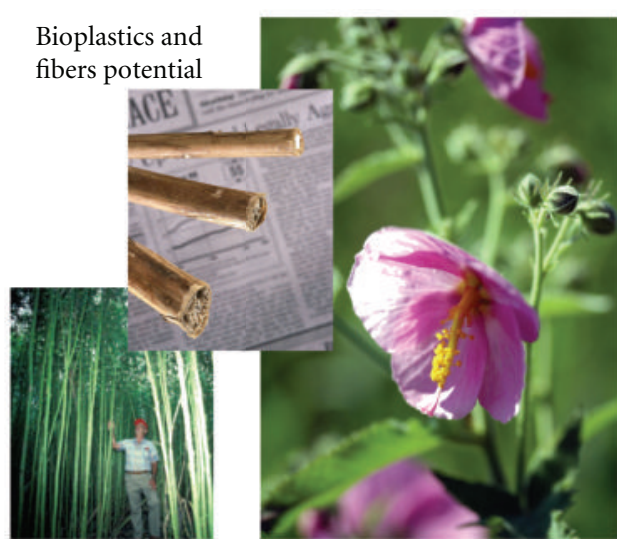

Kosteletzkya virginica

(seashore mallow)

FIGURE 2: Malvaceae family [8-10] with halophyte seashore mallow (kosteletzkya virginica).

TABLE 3: Halophyte water requirements and salt tolerance.

\begin{tabular}{llc}
\hline Halophyte & Salt tolerance & Water requirements, ${ }^{*} \mathrm{~L} / \mathrm{kg}$ \\
\hline $\begin{array}{l}\text { Seashore Mallow, } \\
\text { perennial [53] }\end{array}$ & salt tolerant to coastal seawater & $<1.5$ times glycophyte irrigation $(<1500-3000)$ \\
$\begin{array}{l}\text { Salicornia, } \\
\text { annual [36] }\end{array}$ & $\begin{array}{l}\text { salt tolerant to 2 times seawater, optimum productivity to } 1.3 \\
\text { times seawater }\end{array}$ & 1.35 times glycophyte irrigation $(1300-2700)$ \\
\hline
\end{tabular}

* Prevents salt buildup at roots—soil texture, drainage, natural rainfall, evapotranspiration dependent.

3.2 tonne/ha $35 \%-45 \%$ oil, and is high in omega- 3 with crop residue potential as pyrolysis fuel.

Castor Bean (Ricinus communis), a promising weed-tocrop, provides a low-maintenance, nonedible alternative that does not compete with food use of arable land. Castor seeds have a naturally high oil content $(40-60 \%$ by mass rich in triglyceride, ricinolein) with a projected crop yield of 45 tonne/ha on semiarid lands. Castor oil can be produced from Ricinus communis seed and is like camelina with less demand for water. Compared to petroleum diesel in the US, life cycle analysis (LCA) for castor bean varieties biodiesel shows a $90 \%$ reduction in greenhouse gases (GHG), and the Honeywell UOP company has processed castor to qualify as HRJ biofuel [38]. One downside to Castor is the containment of a toxin called ricin. Ricin is found in the seed, but not in the oil extracted. It can cause problems for harvesting and processing, but the toxin can be denatured by heat during processing.

Pennycress (Thlaspi arvense), a weed becoming a crop, claims 2.25 tonne/ha oil seed with $36 \%$ oil/seed and a potential to produce $920 \mathrm{~L}$-biodiesel/ha (98 gal/acre) on Illinois farmland, which competes with arable land and freshwater resources $[39,40]$.

\section{Cellulosic Biomass}

Worldwide, 4 billion tons of crop residue are produced, with 0.5 billion tons in the United States. Unattended lignocellulosic biomass residuals (e.g., straw, corn stover, and some roadside grasses) have a potentially negative economic and environmental value. Such residuals are of little value as ruminant feed, require fungicide prior to the next crop, bind nutrients while biodegrading, and harbor pathogens if not burned or release $\mathrm{CO}_{2}$ if they are [7, page 195]. They appear, however, as candidates for pyrolysis or fermentation fuels. One ton lignocellulosic biomass produces $100 \mathrm{gal}$ ethanol [41]. However, Lal and others [41-44] point out that crop residues are a commodity essential to the soil. They control erosion, recycle nutrients, and maintain soil structure and tillage, sustaining biomass agronomic yield. Indiscriminant conversion of biomass to energy is wasteful of a commodity essential to soil health. Thus soil carbon can be remediated or produce power, but not both, where removing more than $70 \%$ biomass residuals is considered harmful. Lal [41] suggests proper life cycle analysis, soil residue management, and choosing appropriate warm-season grasses, some perennials and halophytes, which will respond in brackish or seawater in arid regions.

Potentially, the United States could produce 35 billion gal ethanol from crop residues. Producing fuels from lignocellulose is not novel or new, as it was practiced prior to and during WWII, but the challenge is large-scale production of sustainable economically viable renewable lignocellulose fuels [45-48].

Water hyacinth (Eichhomia crassipes), a tropical plant that will remediate waste water, was investigated by Dr. Bill C. Wolverton (NASA-Stennis, retired) under the NASA (NSTL) vascular aquatic plant program. Considered a noxious weed, it produces 5-10 kg-biomass $/ \mathrm{m}^{2}-\mathrm{yr}$ (similar to macroalgae), a source of pyrolysis fuels with beneficial water treatment 


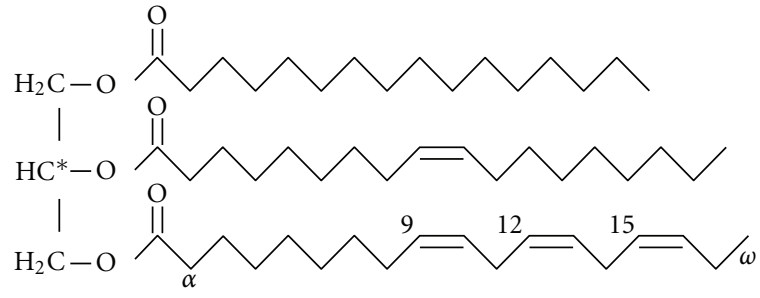

Figure 3: Triglyceride (TAG) C55H98O6 [11] see also Zamora [12].

[49-51]. Another noxious weed is Kudzu with similar pyrolysis benefits with roots a source of starch and some edible leaves.

Other plants such as giant reed (Arundo donax) produce 23-50 ton/acre. It tolerates some salinity and brackish waters and also overwhelms native vegetation. Seaweed, a macroalgae, has enormous potential in the Sargasso seas as a cellulosic fuel and food source.

Honge (Pongamia pinnata), like jatropha, palm, and coconut, is but a few of the trees producing oil seeds that are processed into biodiesel. Experiments show that Honge tolerates brackish water and needs little nitrogen fertilizer, with oil yields similar to palm. Honge and jatropha are both toxic [52].

\section{Processing}

Market oil grades range from unrefined (crude) to refined, bleached, and deodorized (RBD) oils (food grade). RBDquality oil processes are degumming, neutralization, bleaching, hydrogenation, deodorization, and winterization or crystallizations, but for RB grade degumming and bleaching usually reduces contaminants to acceptable levels.

Tree-plant oils (e.g., palm, coconut, jatropha, olive, etc.) as well as vegetable oils (e.g., soybean, canola, rapeseed, camelina, castor, etc.), algae oils, and animal fats are all analyzed for specific contaminants ( $\mathrm{Na}, \mathrm{P}, \mathrm{Ca}, \mathrm{N}$ species), which would determine the extent of contaminant removal (clean-up) required. Phospholipids are typical contaminant species removed during degumming as are nitrogen or amino groups found in algae oils. Tar and ash found in biomass-to-oil processes (e.g., low-temperature biomass gasification) are unsuitable for the processors such as that used by UOP and are generally not found in vegetable oil feedstocks. Common vegetable oil fuel feedstocks include palm, rapeseed, soybean, jatropha, castor, and the lesser known halophytes such as salicornia and seashore mallow.

Holmgren et al. [54] note that RB biomass triglyceride feedstocks contain oxygen, which complicates catalytic processing into biojet fuel. An illustration of seed-oil triglycerides is shown in Figure 3 [11], where the glycerol skeleton (on left) has coupled with three fatty acids: palmitic (top chain), oleic acid (middle chain), and $\alpha$-linolenic acid (bottom chain).

Holmgren et al. [54] make direct use of existing technologies, including blending or coprocessing, to produce renewable diesel fuels that are primarily paraffins rather than esters. Such fatty acid methyl esters (FAMEs) are common in biodiesel.

Hydroprocessing by decarboxylation and hydrodeoxygenation removes oxygen from the three-carbon structure of the triglyceride molecules, yielding green-diesel along with propane that is recovered in the refinery process and waste. The product consists only of paraffins, as all olefinic bonds are saturated, and has no sulfur or aromatics [54]. The oxygen waste is rejected as $\mathrm{CO} / \mathrm{CO}_{2}$ or water, whereas in the FAME process, recovery of methanol and $\mathrm{NaOH}$ are necessary, as is the disposal of glycerol. Holmgren et al. [54] compares the two process streams as follows.

\section{Biodiesel}

$$
\begin{aligned}
& \text { Triglycerides }+ \text { Methanol } \longrightarrow \text { FAME + Glycerol } \\
& 100 \mathrm{bbl} \quad 13 \mathrm{bblNaOH} 99 \mathrm{bbl} 8 \mathrm{bbl}
\end{aligned}
$$

\section{Green Diesel}

Triglycerides $+\mathrm{H}_{2} \longrightarrow$ Green Diesel $+\frac{\mathrm{H}_{2} \mathrm{O}}{\mathrm{CO}_{2}}+$ Propane

$100 \mathrm{bbl} \quad$ catalyst $99 \mathrm{bbl}$ waste $9 \mathrm{bbl}$

\section{Alternate Fuels Processed Barrels}

It is instructive to compare fuels obtained from a barrel of unprocessed oil (Figure 4). A barrel of petroleum produces about 28 gal of general transportation fuel and 3.8 gal jet fuel ( 1 bbl-oil $=42$ gal, 1 bbl-processed-oil $=44.6$ gal $)$. A barrel of processed biomass oil provides 29 gal green jet and 13 gal of naphtha that can be further processed to fuels. A similar process converts a barrel of biomass oil to 40 gal green diesel. In discussing replacement of petroleum, the oil feedstock and most importantly the processing must be taken into account.

The UOP green diesel and HRJ biojet processes are designed for the conversion of triglycerides or free fatty acids, where the raw oil clean-up process conversion loss is less than $5 \%$. Most feedstocks have the same C-chain length (18-22) but differ in number of double bonds and propensity to form free fatty acids [12]. The UOP process can also convert FAME (biodiesel, the fatty acid methyl ester), algae oils (which are similar), and animal fats (which are also very similar) [14].

\section{Aviation Fuel Standards}

JetA-1 fuel must satisfy ASTM D1655. Fischer-Tropsch-(FT-) derived fuels (e.g., from coal (CTL) or natural gas (GTL)) must satisfy ASTM D7566 Aviation Turbine Fuel Containing Synthesized Hydrocarbons (August 4, 2009) [55], a parallel to MIL-DTL-83133F (11 April 2008), regulating 50:50 blends with JetA-1 and JP-8, respectively. Biojet (HRJ) has specific requirements beyond those of green diesel in that it must satisfy ASTM D7566 with anticipated approval of fuel blends in 2010-2012 [56]. One of the first hurdles a 

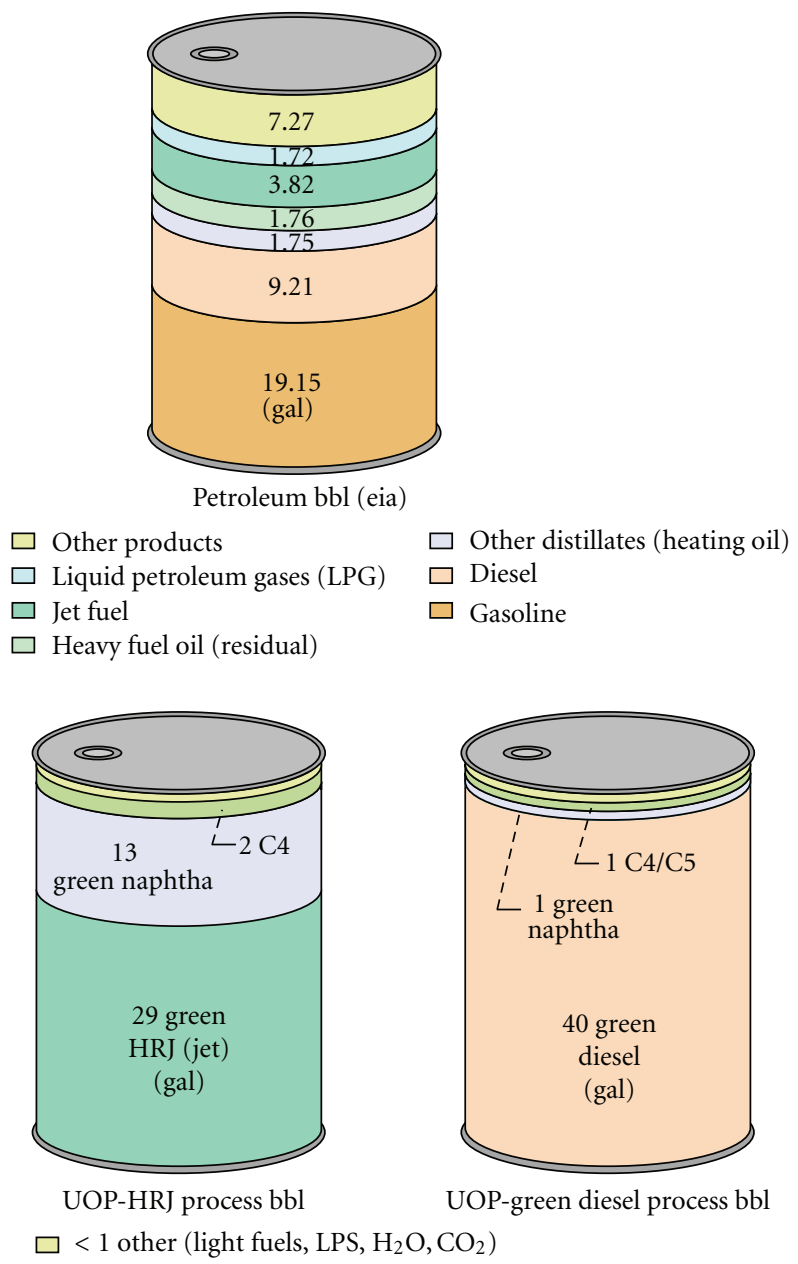

FIGURE 4: Gallons of distillates from a barrel of oil [13] and liquid sunshine processes UOP HRJ and green diesel [14].

potential fuel must pass is the freezing point test, $-47^{\circ} \mathrm{C}$. Other companies (e.g., Syntrolem) can also process seed oils to biojet. CAAFI has recognized SPK-HEFA (SPK from hydroprocessed esters and fatty acids) as an alternate name to HRJ fuel.

\section{SPK and HRJ Carbon Spectra}

Although the carbon distributions of SPK and HEFA fuels differ widely, they qualify as jet fuels under ASTM D7566 specifications. When blended up to $50 \%$ with petroleumbased JetA-1 or JP-8, they provide "drop in" fueling replacements for aircraft. The weight percents for three biojet flight fuels_camelina (Japan Airlines), jatropha (Air New Zealand), and jatropha algae (Continental Airlines)—shown in Figure 5, illustrate similar carbon-number distributions. The high isomer: normal-paraffin ratio across the carbonnumber distribution also provides vegetable oils with lower freezing points.

\section{Alternate-Fueled Flight Tests}

In the late 1800s, the US alternate fuels industry produced quantities of oils (e.g., coal oil) that were replaced by cheap oil. The use of synthetic FT fuels became prominent in Germany during WWII, yet it could not be sustained because of bombings and controlled use of petroleum fuels. In response to sanctions imposed on hydrocarbon fuel imports, South Africa became a world leader in production and use of FT synthetic jet fuels. More recently, the Air Force Research Laboratory (AFRL) took the initiative to test, fly, and certify aircraft for FT-fuel blends to 50\% with JP-8, with several commercial airlines flight testing alternate fueling as illustrated in Figure 6 and in the following list.

As of June 2009, SPK- and SPK-HEFA-fueled flights have had no discernable problems, with ASTM (D7566-Annex) approval (2011).

Recorded alternate-fueled flights include the following.

(1) August 8, 2007: USAF B52H

Aircraft flight certified

Fuel blends up to 50\% synjet (SPK) with JP-8

SPK fuel specification MIL-DTL-83133F.

(2) February 24, 2008: Virgin Atlantic 747-400 40-min biojet fueled flight

One of four GE CF6-80C2B5F turbofan engines London to Amsterdam $(320 \mathrm{~km})$ altitude to $(7.6 \mathrm{~km})$ 


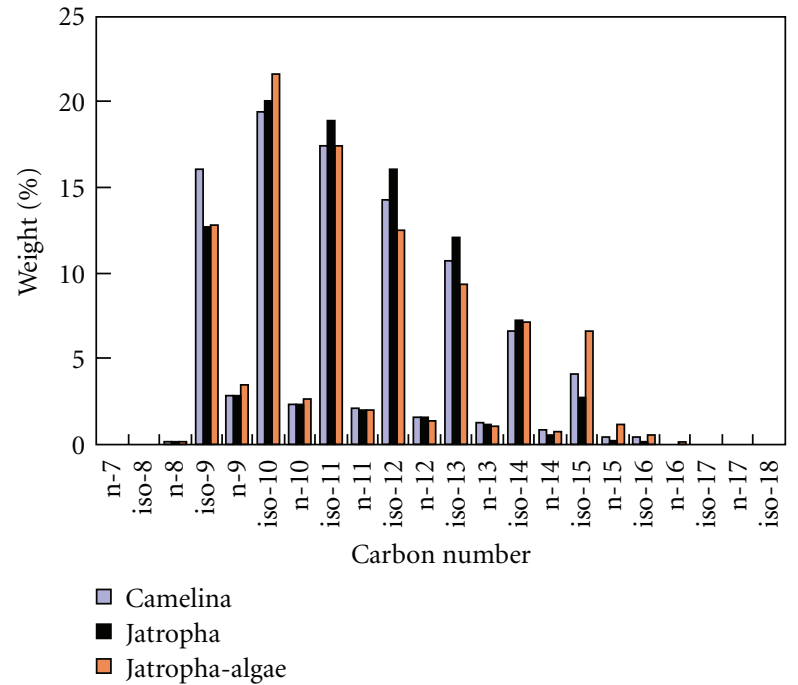

FIGURE 5: Relative weight percent carbon spectra for camelina, jatropha, and jatropha-algae flight fuels blended with JetA-1. Jennifer.Holmgren@uop.com.

80\% JetA-1: 20\% processed coconut oils

Ground tests to 60JetA : 40biojet no discernable problems.

(3) February 1, 2008: Airbus A380 3-hr GTL fueled flight

One of four Rolls-Royce Trent 900 engines fueled

Bristol to Toulouse to assess environmental impact

GTL (gas-to-liquid) fueling 50\% JetA-1: 50\% GTL Blend

Goal regulatory 50:50 blend (2009): 100\% GTL (2013).

(4) December 30, 2008: Air New Zealand, 747-400 2-hr biojet fueled flight

One of four Rolls-Royce RB211engines fueled

Auckland over Hauraki Gulf

Fueled 50:50 blend processed-jatropha UOP biojet and JetA- 1 .

(5) January 7, 2009: Continental 737-800 $1.5 \mathrm{hr}$ biojet fueled flight

One of two GE CFM56-7B engines fueled

Flight over Gulf of Mexico

Fueled $50: 50$ blended biofuel of (47.5\% jatropha + $2.5 \%$ algae) UOP biojet + JetA-1

Pilot reported enhanced fuel economy.

(6) January 30, 2009: JAL 747-300 $1.5 \mathrm{hr}$ biojet flight

Number 3 P\&W JT9D engine fueled

Flight about Haneda Airport

Fueled $50: 50$ blend biojet:Jet-A [feedstocks camelina $84 \%$ (sustainable oils), jatropha (Terrasol) $<16 \%$, and algae $<1 \%$ (Sapphire) UOP processed].
Organizations contributing to alternate-fueled flight include the Commercial Aviation Alternate Fuels Initiative (CAAFI) in areas of research, emissions, business, and regulations; and the Transportation Research Board (TRB) in areas of road, rail, air, marine, and transit.

For more details see Hendricks [19].

\section{General Aviation (GA) and Unmanned Aerial Vehicles (UAV)}

GA is seeking environmentally friendly carbon-neutral biomass fueling (biofuels) as future fueling replacement for aviation gas (Av-gas).

The US piston fleet represents $71.4 \%$ of GA aircraft, a total of 165,189 aircraft, which represents a significant number of planes and pilots that need assistance in transitioning from Av-gas to biomass fueling. The Café Foundation [57] was established to enable alternate-fueled GA flight based on environmentally sound principles with a carbon neutral/negative footprint.

The number of aircraft in the USA-GA fleet (excludes military, airlines, charter operations, and aircraft of over $12,500 \mathrm{lb}$ ) is 213,488 , and these are typified in the $2006 \mathrm{Nall}$ Report [58].

One of NASA's general aviation (GA) engine programs, originating in the mid-90s, is summarized in a work presented at Burkhart [59].

Early aviators used gasoline (80/87) octane ratings. Fuels developed in the 1950s and 60s for GA use were a blend of naptha alkylate (mixture of isooctanes and some reformate), which along with tetra-ethyl-lead $(\mathrm{TEL}=1.12 \mathrm{~g} / \mathrm{L})$, enabled $100 / 130$ octane ratings for lean/rich engine fueling mixtures (e.g., cruise and take off). These fuels for the most part have been replaced by 100LL (low lead TEL $=0.56 \mathrm{~g} / \mathrm{L}$ (Figure 7) [60]. Av-gas will be the C8 (carbon number), as it is predominantly alkylate (made from two $\mathrm{C} 4$ compounds). The JP-8 spectra will pick up where the Av-gas leaves off with little overlap. The volatility is typically controlled by blending in isopentane so there will be C5 present as well [61].

Potential biofuel replacement feedstocks for Av-gas include halophytes, algae, bacteria, "weeds-to-crops," and wastes. However, nearly all feedstock oils can be UOPprocessed to biojet fuel; that is, nearly feedstock independent [54], and with demand, the process could be modified to produce bio-Av-gas for both civil and military (Figure 8 [3032]) GA applications.

General aviation requirements differ in that pistonengine-type aircraft require different fueling. Still, the processed biofuel stream could be diverted to a secondary processing stream to meet those specifications for both highoctane fuels and diesel, resulting in drop-in replacements for low-lead aviation gas.

\section{Infrastructure}

Postprocessing fueling distribution infrastructure includes pipeline, storage, airport, and aircraft fueling systems. Most of these systems exist and are applicable or adaptable to 

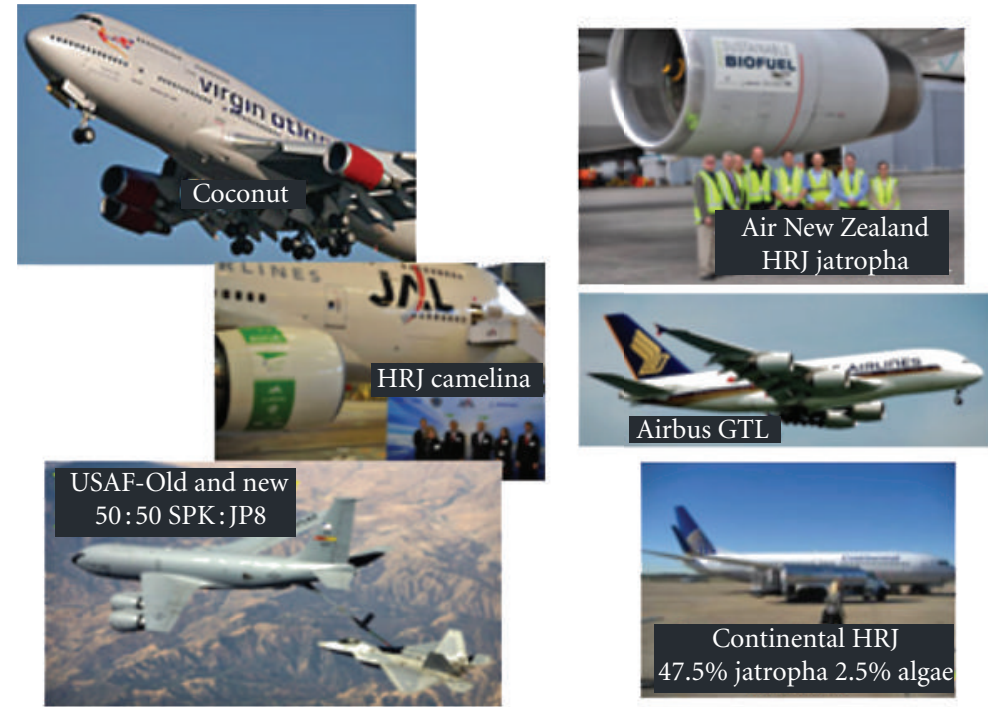

FIGURE 6: Alternate-fueled flight testing.

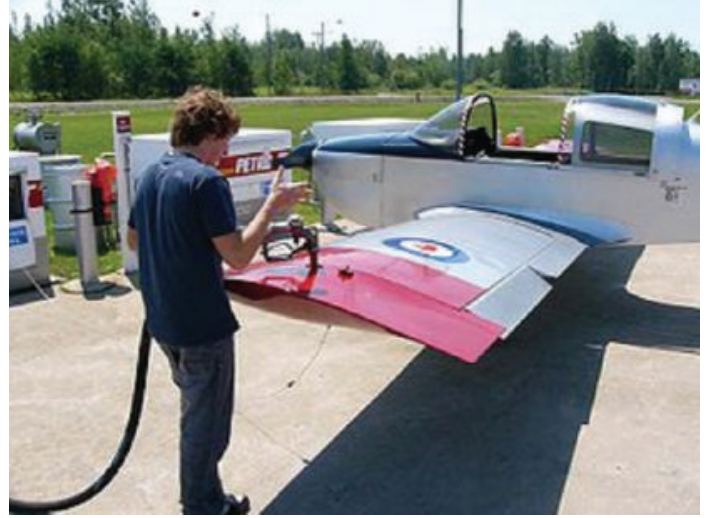

Figure 7: An American Aviation AA-1 Yankee being refueled with 100LL Av-gas [29].

a variety of processed biofuel feedstocks. Even though the processes, such as UOP's, have a wide range of applicability, it is difficult to predict future feedstocks. Further, processplant and fueling infrastructure life needs to exceed 20 years, requiring long fabrication-to-operation lead times with price stability and support.

\section{Economics}

Currently, the biomass industry is dealing with highly volatile regulations $[31,32,62]$, life cycle analysis, and costing issues $[3,20,32]$. Most biomass-to-oil startup companies advertise costs at or just above the DARPA targets of $\$ 1-\$ 2 /$ gal [63], which is half of the Daggett et al. [3] optimistic projection for algae oils and at least order of magnitude less than common market algae oils. Even established markets for crops such as palm and soybeans struggle to survive fuel cost and political barriers. Until biomass oils enjoy similar support and subsidies as petroleum, including costs of security and

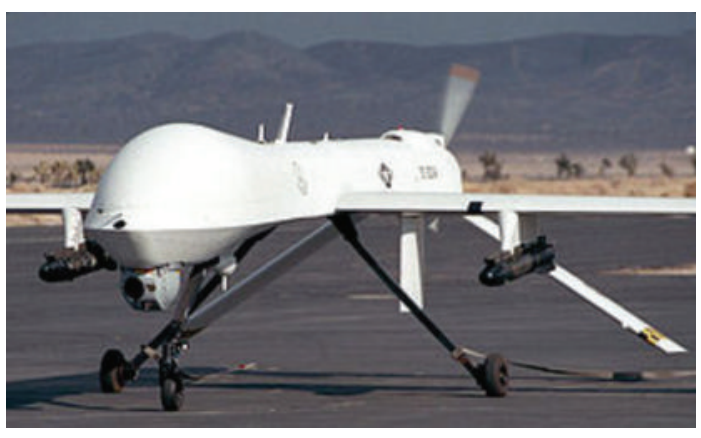

Figure 8: Rotax 914, a four-cylinder, four-stroke, 101-horsepower engine, the same engine type commonly used on snowmobiles, rotates the Predator's two-blade, variable-pitch pusher propeller [30-32].

defense, they simply cannot compete with drilled petroleum production at less than $\$ 2 / \mathrm{bbl}$. Price stabilization could enable investor assessment of risk, projected value, and return on investment. Successfully investing in biomass growth and production also creates more farming and production jobs in diverse areas. Biomass such as halophytes has the potential to create crops from land that was previously not arable, increasing personal and government property productivity.

World aviation conversion to biojet fueling in today's transportation market becomes marginal unless vegetable oils, which in today's market trade at a higher price than petroleum on a per barrel basis, become cost effective, secure, sustainable, and of sufficient supply. Biofueling is high risk, high payoff, and existential to survival.

\section{Concluding Remarks}

Producing transportation fuels that can be blended with petroleum to meet political, social, environmental, and 
legacy transport systems requirements becomes an opportunity of enormous proportions.

Aviation fueling is particularly important, as safety is a paramount issue, and very specific fueling needs and requirements have to be met. To date, specifications for synthetic paraffinic hydrocarbon fuels (SPK) primarily from coal (CTL) or gas (GTL) and SPK-HEFA have been established for MIL- and ASTM-approved SPK and biojet blended fuels, with demonstrated flight performance to $50: 50$ blends. Sources of coal and gas are well established. Now begins the difficult task of determining what the fueling feedstock sources and resources are and how biomass such as halophytes, algae (micro and macro), bacteria, weeds-tocrops, and wastes can meet aviation fueling needs.

Concurrent demands from the aviation industry to increase fuel availability and reduce fuel consumption and emissions can be met with biomass-derived fuels.

(1) Traditional biofuels (corn, soybeans, and palm), which rely on freshwater and arable land, essentially lack the capacity and solutions provided by nontraditional feedstocks such as halophytes, algae, cyanobacteria, and "weeds."

(2) Biojet fuels from sources such as halophytes, algae, cyanobacteria, and "weeds" (e.g., jatropha, castor, and camelina) that use wastelands, waste water, and seawater have the capacity to be drop-in fuel replacements for petroleum fuels without the downsides of "conventional" biofuels as listed above. These fuel feedstocks are also restrained by self-imposed restraints to not compete with food or feed crops, freshwater needs, or the social fabric, nor are they detrimental to the environment.

(3) Biomass fuels must utilize, recycle, and sequester existing and exhausted atmospheric carbon $\left(\mathrm{CO}_{2}\right.$ and emissions in general) along with soils remediation if they are to be truly "green" and useful in combating climate change to the extent possible. Biojet fuel from such sources SOLVES the aviation $\mathrm{CO}_{2}$ emissions issue.

(4) The use of cellulosic waste residuals-whether crop, forestry, or other-requires a form of pyrolysis or fermentation in order to be further processed to satisfy jet fuel requirements. Disagreements persist relative to residue removal in terms of pathogens and use of soil fumigants as well as soil carbon requirements, which require resolution.

(5) Biojet fuel blends to 50:50 with Jet A-1 have been flight tested with no discernable problems. An ASTM specification has been approved, and SPK blended to $50: 50$ has also received approval. Currently, most military aircraft are certified to fly on alternative fuels of only 50:50 blends. The MIL or ASTM fueling requirements are fully satisfied, though there are significant variations in the carbon distribution of the various SPK and biojet fuels produced from various feedstocks. Limitations in alternate fuel processing looking at producer investment and profit margins, as well as major concerns such as freshwater usage and conflict with food production, have hindered testing more potent alternate fuel blends for the time being. These 50:50 blends still represent a forward step and are an encouraged option.

(6) Cost is the major issue of biomass fueling, or for that matter alternate fueling in general. Algae has a major cost problem. However, halophytes simply involve more farming, at (acceptable) the usual farming costs (similar to cellulosic). Therefore, halophytes are the near-term solution to biomass/biofuels capacity at reasonable costs and without use of freshwater or arable land. Much effort in research, development, and investments into nontraditional crops is required to enable the same levels of support that traditional biomass agriculture enjoys.

Renewable energy approaches, each of which can replace all of the "fossil" fuel demands, are drilled geothermal, solar photovoltaic, solar thermal, and biomass sourced from halophytes, algae, cyanobacteria, or "weeds" on wastelands using waste or salt water. Wind and wastes are secondary sources of energy, with energy from wastes based on pyrolysis or fermentation processes. Biofuels represent a win-win approach by offering a large productive capacity, carbon emission neutrality, and ultimately, reasonable costs.

\section{Acknowledgment}

The authors would like to thank Nikita T. Saxena and Anna E. Thomas for their assistance in reorganizing the paper.

\section{References}

[1] J. Reilley, S. Paltsev, and F. Choumert, "Heavier Crude, Changing Demand for Petroleum Fuels, Regional Climate Policy, and the Location of Upgrading Capacity: A Preliminary Look," MIT Joint Program on the Science and Policy of Global Change, Report No. 144, Massachusetts Institute of Technology, Cambridge, Mass, USA, 2007, http://web.mit.edu/globalchange/www/MITJPSPGC_Rpt144.pdf.

[2] Energy Information Administration, "Chapter 1-World Energy Demand and Economic Outlook," International Energy Outlook 2009, Report \#:DOE/EIA-0484(2009), http:// www.eia.doe.gov/oiaf/ieo/world.html.

[3] A. Sun, R. Davis, M. Starbuck, A. Ben-Amotz, R. Pate, and P. T. Pienkos, "Comparative cost analysis of algal oil production for biofuels," Energy, vol. 36, no. 8, pp. 5169-5179, 2011.

[4] D. Daggett, O. Hadaller, R. Hendricks, and R. Walther, "Alternative fuels and their potential impact on aviation," in the 25th International Congress of the Aeronautical Sciences (ICAS '06), Hamburg, Germany, 2006.

[5] D. L. Daggett, R. C. Hendricks, R. Walther, and E. Corporan, "Alternate fuels for use in commercial aircraft," in the 18th ISABE Conference, Beijing, China, 2007.

[6] R. C. Hendricks, "Sustainable secure alternate aviation fueling," in NASA Seal/Secondary Air System Workshop, vol. 1, pp. 75-99, Cleveland, Ohio, USA, 2007.

[7] J. Gressel, Genetic Glass Ceilings: Transgenetic for Crop Biodiversity, Johns Hopkins University Press, Baltimore, Md, USA, 2008. 
[8] Wikipedia, “Cotton,” 2009, http://en.wikipedia.org/wiki/Cotton.

[9] Wikipedia, “Okra," 2009, http://en.wikipedia.org/wiki/Okra.

[10] Wikipedia, "Kenaf," 2009, http://en.wikipedia.org/wiki/Kenaf.

[11] Wikipedia, “Triglyceride," 2009, http://en.wikipedia.org/wiki/ Triglyceride.

[12] A. Zamora, "Fats, Oils, Fatty Acids, Triglycerides," Scientific Psychic, 2005, http://www.scientificpsychic.com/fitness/fattyacids.html.

[13] Energy Information Administration, "Nonrenewable Oil (Petroleum)," 2009, http://www.eia.gov/kids/energy.cfm? page $=$ oil_home-basics\#Howused.

[14] J. Holmgren, UOP LLC, private communication, 2009.

[15] J. Gressel, "Why transgenics are imperative for biofuel crops," OAI-NASA Lecture, Ohio Aerospace Institute, Brook Park, Ohio, USA, March 2009.

[16] M. Palaniappan and P. H. Gleick, "Peak water," in The World's Water 2008-2009: The Biennial Report on Freshwater Resources, P. H. Gleick, Ed., Water Content of Things, chapter 1, and data table 19, pp. 335-338, Island Press, Washington, DC, USA, 2009.

[17] M.-W. Ho and J. Cummins, "Saline agriculture to feed and fuel the world institute for science in society," ISIS Report 24/02/09, The Institute of Science in Society, London, UK, 2009, http://www.i-sis.org.uk/SalineAgriculture.php.

[18] R. C. Hendricks and D. M. Bushnell, "Halophytes energy feedstocks: back to our roots," in the 12th International Symposium on Transport Phenomena and Dynamics of Rotating Machinery, Honolulu, Hawaii, 2008.

[19] R. C. Hendricks, "Alternate-Fueled Flight: Halophytes, Algae, Bio-, and Synthetic Fuels," NASA/TM-2009-215222, 2009, http://www.atlanticgreenfuels.com/.

[20] D. Daggett, "Boeing Commercial Airplanes," Seattle Wash, USA, private communication, 2009.

[21] R. C. Hendricks and D. M. Bushnell, "Synthetic and biomass alternate fueling in aviation," in NASA Seal/Secondary Air System Workshop, pp. 91-130, Cleveland, Ohio, USA, 2008.

[22] T. Burton,, H. Lyons, Y. Lerat, M. Stanley, and M. B. Rasmussen, "A review of the potential of marine algae as source of biofuel in Ireland," Sustainable Energy Ireland (SEI), Glasnevin, Dublin 9, Ireland, 2009.

[23] A. Ben-Amotz, J. E. W. Polle, and D. V. S. Rao, The Algae Dunaliella Biodiversity, Physiology, Genomics and Biotechnology, Science Publishers, Enfield, NH, USA, 2009.

[24] R. C. Hendricks and D. E. Bushnell, "Synthetic and Biomass Alternate Fueling in Aviation," Mechanical Engineering Today, 2009, http://www.asme.org/NewsPublicPolicy/Newsletters/ METoday/Articles/Synthetic_Biomass_Alternate.cfm.

[25] Algal Biomass Organization-Algae for Energy, "Algal Biomass Events," 2009, http://www.algalbiomass.org/events/.

[26] University of Michigan, "Researchers Predict Large 2009 Gulf of Mexico 'Dead Zone', Space \& Earth, Ann Arbor, Mich, USA, 2009, http://www.physorg.com/print164546116.html.

[27] J. Dearen, "Killer Miso Soup Kelp Invades San Francisco Bay," The Huffington Post, July 2009, http://www.huffingtonpost .com/2009/07/13/killer-miso-soup-kelp-inv_n_230836.html.

[28] Baltic Sea Solutions and STP Productions, "Presentations," in Wind-Sea-Algae: International Workshop on Offshore Algae for Biofuels and Beyond, Lolland, Denmark, 2009.

[29] Wikipedia, “Avgas," 2009, http://en.wikipedia.org/wiki/Avgas.

[30] R. Valdes, "How the Predator UAV Works," HowStuffWorks, Inc., Atlanta, Ga, USA, 2009, http://science.howstuffworks .com/predator1.htm.
[31] Rotax Aircraft Engines, “914," BRP-Rotax GmbH \& Co. KG, Gunskirchen, Austria, 2009, http://www.rotax-aircraftengines.com/desktopdefault.aspx.

[32] Thielert Aircraft Engines, Hamburg, Germany, 2009, http:// www.thielert.com/.

[33] S. R. Schill, "Exxon Announces \$600 Million Algae Project," Biodiesel Magazine, Grand Forks, ND, USA, 2009, http:// www.biodieselmagazine.com/article.jsp?article_id=3586\&q= venter\&category_id $=5$.

[34] A. Ben-Amotz, personal communication, NBT Ltd., Eilat, Israel, 2008.

[35] L. V. Beloussov, V. L. Voeikov, and V. S. Martynyuk, Photonics and Coherent Systems in Biology, Springer Science and Business Media, LLC, New York, NY, USA, 2007.

[36] Carl N. Hodges, Chairman, The Seawater Foundation, 3002 E. Hawthorne Street, Tucson, AZ 85716; Co-Chairman, New Nile Co http://www.newnileco.com/.

[37] K. A. McVay and P. F. Lamb, "Camelina Production in Montana," MontGuide, Montana State University Extension, Bozeman, Mont, USA, 2008, http://msuextension.org/publications/AgandNaturalResources/MT200701AG.pdf.

[38] Evogene News \& Press, "Life Cycle Analysis of Evogene Castor Bean based Biodiesel Shows 90\% Emissions Reduction Compared to Petroleum," Rehovot, Israel, 2010, http://www .evogene.co.il/news.asp?new_id=91.

[39] Wikipedia, “Thlaspi Arvense," 2009, http://en.wikipedia.org/ wiki/Thlaspi_arvense.

[40] S. R. Schill, "Making Pennycress Pay Off," Biodiesel Magazine, Grand Forks, ND, USA, 2008, http://www.biodieselmagazine.com/articles/2047/making-pennycress-pay-off/.

[41] K. Lal, "There is no such thing as a free biofuel from crop residues," CSA News, vol. 52, no. 5, pp. 12-13, 2007.

[42] Washington State University, "Crop Residue May Be Too Valuable To Harvest For Biofuels," Science Daily, Rockville, Md, USA, 2008, http://www.sciencedaily.com/releases/2008/07/080715190110.htm.

[43] United States Department of Agriculture and National Resources Conservation Service, "Crop Residue Removal for Biomass Energy Production: Effects on Soils and Recommendations," Soil Quality-Agronomy Technical Note No. 19, Washington, DC, USA, 2006, http://soils.usda.gov/ sqi/management/files/sq_atn_19.pdf.

[44] D. A. Glassner, J. R. Hettenhaus, and T. M. Schechinger, "Corn Stover Collection Project," BioEnergy '98: Expanding BioEnergy Partnerships, U.S. Department of Energy, Madison, Wis, USA, 1998, http://www.nextstepbiofuels.com/ PR/TalkingAboutCornStover.pdf.

[45] J. Regalbuto, "NSF Biofuels Activities," BRDI TAC Meeting, National Science Foundation, Arlington, Va, USA, 2008, http://www.usbiomassboard.gov/pdfs/regalbuto_bciwg_tac_ nsf.pdf.

[46] Virent Energy Systems, Inc, Madison, Wis, USA, 2007, http://www.virent.com/.

[47] Y. Y. Hsu, "Clean fuels from biomass," in the 10th Southeastern Seminar on Thermal Sciences, New Orleans, La, USA, 1974.

[48] R. W. Graham, T. W. Reynolds, and Y. Y. Hsu, "Preliminary Assessment of Systems for Deriving Liquid and Gaseous Fuels From Waste or Grown Organics," NASA TN D-8165, NASA Glenn Research Center, Cleveland, Ohio, USA, 1976, http://ntrs.nasa.gov/archive/nasa/casi.ntrs.nasa.gov/19760011589_1976011589.pdf.

[49] B. C. Wolverton and K. Takenaka, Plants: How They Contribute to Human Health and Well-Being, Roli Books, New Delhi, India, 2009. 
[50] B. C. Wolverton and J. D. Wolverton, Growing Clean Water: Nature's Solution to Water Pollution, Wolverton Environmental Services, Picayune, Miss, USA, 2001.

[51] B. C. Wolverton, How to Grow Fresh Air, Penguin Books, New York, NY, USA, 1997.

[52] Wikipedia, "Pongamia Pinnata," 2009, http://en.wikipedia .org/wiki/Pongamia_pinnata.

[53] University of Delaware, "John L. Gallagher," Newark, Del, USA, 2009, http://www.ocean.udel.edu/people/profile .aspx?jackg.

[54] J. Holmgren, C. Gosling, R. Marinangeli, T. Marker, G. Faraci, and C. Perego, "A new development in renewable fuels: green diesel," in 105th National Petrochemical and Refiners Association (NPRA) Annual Meeting, San Antonio, Tex, USA, 2007, Paper AM-07-10.

[55] Commercial Aviation Alternative Fuels Initiative, "ASTM Passes Synthetic Jet Fuel Specification," 2009, http://www .caafi.org/news/News.aspx?id=39.

[56] Commercial Aviation Alternative Fuels Initiative, "Landmark Synthetic Jet Fuel Specification Passes Critical Hurdle," 2009, http://www.caafi.org/files/altfuelstandard-rls6-09.pdf.

[57] Café Foundation, "CAFE: Comparative Aircraft Flight Efficiency," Santa Rosa, Calif, USA, 2009, http://cafefoundation.org/v2/main_home.php.

[58] AOPA Air Safety Foundation, "2006 Nall Report: Accident Trends and Factors for 2005,” 2006, http://www.aopa .org/asf/publications/06nall.pdf.

[59] L. Burkhart, "Accomplishments of NASA G/A Propulsion Program," Oshkosh paper number 123, EAA AirVenture Oshkosh 2001, Oshkosh, Wis, USA, 2001, http://www.forums4.us/fl2001.html.

[60] EPI Inc, "The Need for Leaded Avgas, Availability Declining Worldwide," 2008, http://www.epi-eng.com/aircraft_engine products/demise_of_avgas.htm.

[61] AVweb Editorial Staff, AVwebFlash, vol. 14, no. 48, 2008.

[62] Global Subsidies Initiative, "Biofuel Subsidies," Geneva, Switzerland, 2009, http://www.globalsubsidies.org/en/research/biofuel-subsidies.

[63] DARPA Strategic Technology Office, "BioFuels-Cellulosic and Algal Feedstocks," BAA08-07, DARPA, Arlington, Va, USA, 2007, http://www.darpa.mil/default.aspx, (search on algae fuel). 

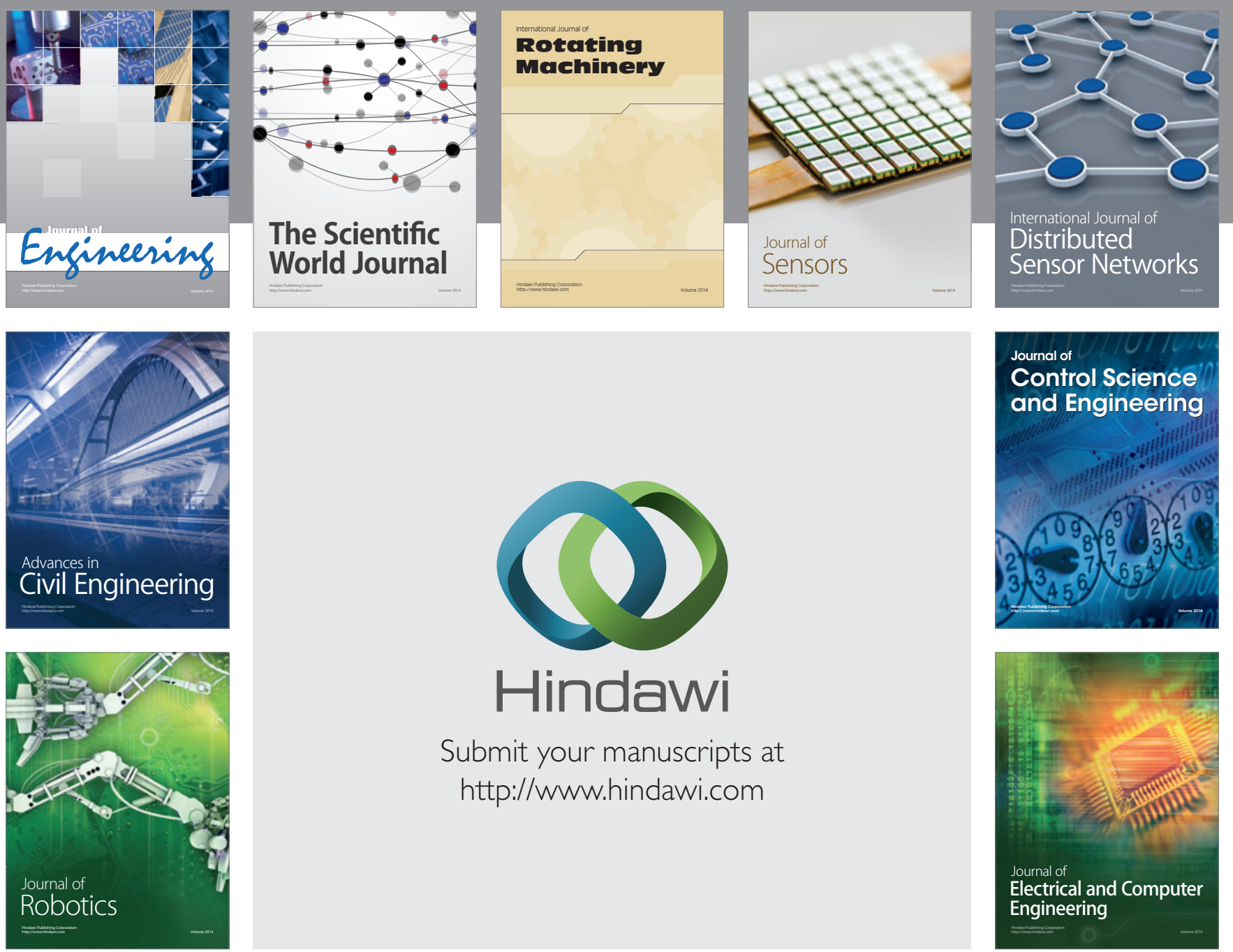

Submit your manuscripts at

http://www.hindawi.com
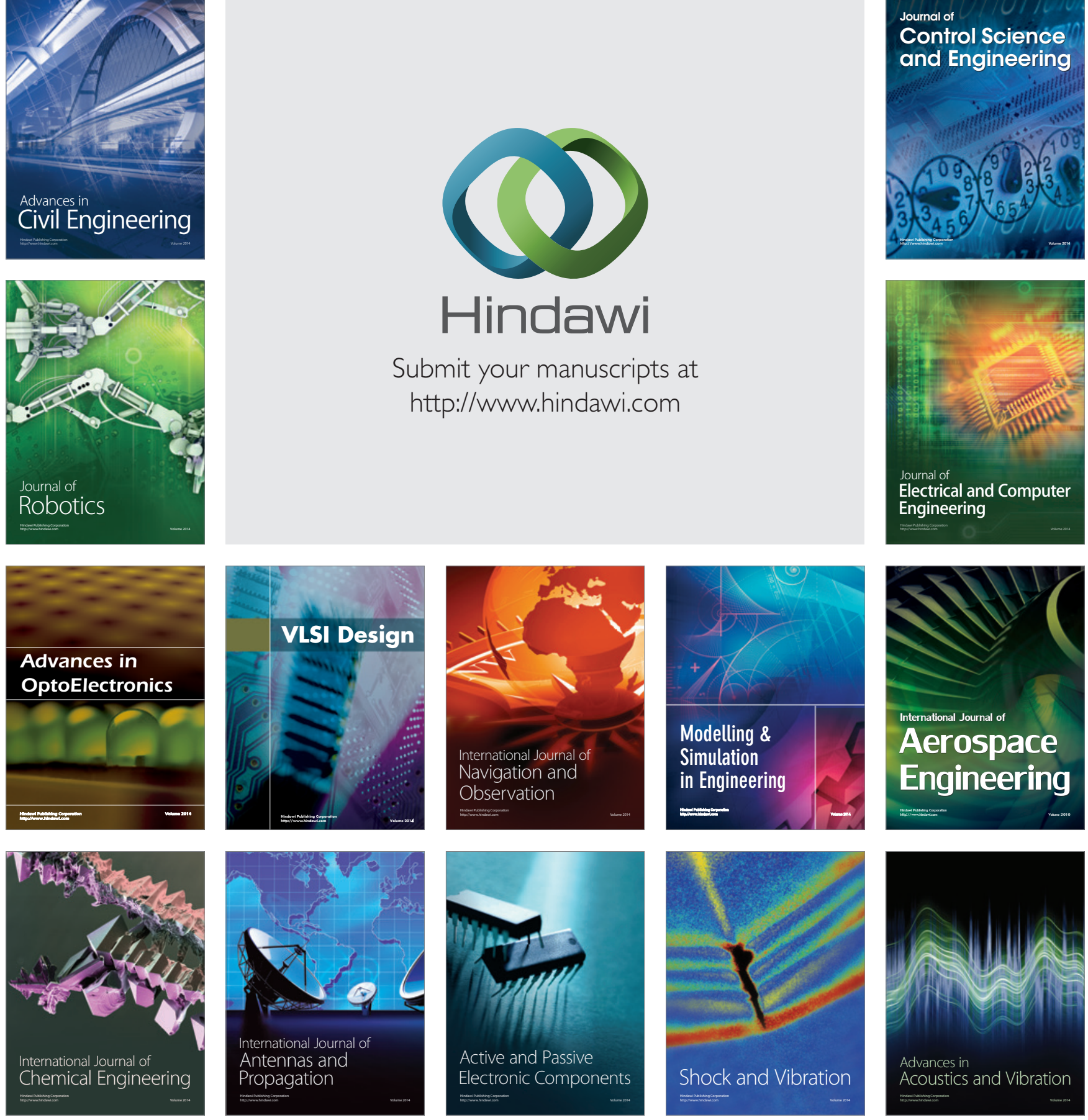